\title{
Breeding Pond Selection and Movement Patterns by Eastern Spadefoot Toads (Scaphiopus holbrookii) in Relation to Weather and Edaphic Conditions
}

\author{
Cathryn H. Greenberg, ${ }^{1,2}$ and George W. Tanner ${ }^{3}$ \\ 'USDA Forest Service, Southern Research Station, Bent Creek Experintental Forest, \\ 1577 Brevard Road, Asheville, North Carolina 28806, USA; \\ E-nail: kgreenbergofs.fed.us \\ ${ }^{3}$ Department of Wildife Ecology and Conservation, \\ Institute of Food and Agricultural Sciences, Box 110430 , \\ University of Florida, Gainesuille, Florida 32611, USA
}

\begin{abstract}
ABSTRACl.-Eastern Spadefoot Toads (Scaphiopus holbrookii) require fish-free, isolated, ephemeral ponds for breeding but otherwise inhabit surrounding uplands, commonly xeric longleaf pine (Pinus palustris) and wiregrass (Aristida beyrichiana) ecosystem. Fire suppression in the Florida sandhills has the potential to alter upland and pond suitability through increased hardwood densities and resultant higher transpiration. In this paper, we explore breeding and metamorphic emigration movements in relation to weather, hydrological conditions of ponds, and surrounding upland matrices. We use nine years of data from continuous monitoring with drift fences and pitfall traps at eight ephemeral ponds in two upland matrices: regularly burned, savanna-like sandhills $(N=4)$, and hardwood-invaded sandhills $(N=4)$. Neither adult nor metamorph captures differed between ponds within the two upland matrices, suggesting that they are tolerant of upland heterogeneity created by fire frequency. Explosive breeding occurred during nine periods and in all seasons; adults were captured rarely otherwise. At the landscape-level, an interaction between rainfall and maximum change in barometric pressure were the top significant predictors of explosive breeding. At the pond-level, rainfall and the change in pond depth during the month prior to breeding were the top significant predictors of adult captures. Metamorphic emigrations occurred following transformation and usually were complete within a week regardless of rainfall levels. Movement by adults and metamorphs was directional, but mean directions of adult emigrations and immigrations did not always correspond. Our results suggest that spadefoot toads are highly adapted to breeding conditions and upland habitat heterogeneity created by weather patterns and fire frequency in Florida sandhills.
\end{abstract}

Eastern Spadefoot Toads (Scaphiopus holbrookii) and several other amphibian species that inhabit the xeric longleaf pine (Pinus palustris)-wiregrass (Aristida beyrichiana) association require fish-free, isolated, ephemeral ponds for breeding, and spend most of their adult lives in the surrounding uplands (Moler and Franz, 1987). Historically, low-intensity, high-frequency fire in the xeric longleaf pine-wiregrass ecosystem maintained a predominantly open, pine-dominated habitat by killing many young hardwood trees (Myers, 1990). Depression ponds also were maintained by fire, when peat and encroaching vegetation were burned during dry periods. Hardwood invasion caused by fire suppression could potentially alter upland conditions by reducing light intensity and herbaceous ground cover, increasing tree and shrub density and leaf litter cover, and altering soil conditions (by increased root masses). Higher transpiration by invasive

\footnotetext{
${ }^{2}$ Corresponding Author.
}

hardwoods could alter pond hydrology (Jansen et al., 2001). Pearson (1955) reported that spadefoot toads are most abundant in forests with little leaf litter and sparse shrubs, suggesting that upland conditions surrounding breeding ponds could affect their populations.

Spadefoot toads exhibit an explosive (Wells, 1977) breeding response to heavy rainfall during short time periods and usually breed in ponds that have refilled after complete drying (Gosner and Black, 1955; Wright, 2002), where invertebrate predator densities are likely reduced. Larvae exhibit rapid development, presumably an adaptive response to the short hydroperiod of ephemeral ponds. Survival and developmental rates also are affected by competition, predation, temperature, and availability of food resources (Gosner and Black, 1955; Wilbur et al., 1983; Wilbur, 1987; Alford, 1989; Petranka and Kennedy, 1999). Hence, the persistence of spadefoot toad populations depends upon suitable conditions that include weather and pond hydrology 
for breeding and the condition of surrounding uplands (Delis et al., 1996).

Several accounts note mass movements of spadefoot toad metamorphs exiting ponds in specific directions (Neill, 1957; Bragg, 1968; Wright, 2002). Pearson (1955) documented homing behavior to upland burrows by spadefoot toads, but little is known about directional movement by adults to and from breeding ponds.

Most aspects of spadefoot toad natural history are derived from observation (Neill, 1957), shortterm studies at one or a few sites (Pearson, 1955; Bragg, 1961), studies in upland habitat (Pearson, 1955), or experiments in artificial environments (Wilbur et al., 1983; Wilbur, 1987; Alford, 1989; Petranka and Kennedy, 1999). Few studies capture a landscape-level perspective of amphibian breeding biology by intensively, concurrently, and continuously sampling multiple sites over an extended period of time.

In this paper, we use data from nine years (February 1994 to January 2003) of continuous monitoring at eight isolated, ephemeral ponds in Florida longleaf pine-wiregrass uplands to explore some aspects of spadefoot toad natural history, and some environmental variables related to pond use. We ask (1) Does the condition (hardwood-invaded or savanna-like) of longleaf pine-wiregrass uplands surrounding ephemeral ponds affect pond use by adults or successful recruitment of metamorphs? (2) How do weather variables relate to movement patterns, specifically, explosive breeding by adults and emigration of metamorphs, at a landscape-level? (3) How do hydrological patterns such as the drying and filling of ponds, water depth, or precipitation affect pond selection by adults for explosive breeding? (4) Are mass movements of adults or metamorphs to and from ponds directional or randomly oriented? Improved understanding of the breeding biology and ecology of spadefoot toads should aid in conservation and restoration planning.

\section{Materials and Methods}

Study Area.-This study was conducted at eight isolated, ephemeral ponds of sinkhole origin in longleaf pine-wiregrass sandhills on the Ocala National Forest, Marion and Putnam Counties, Florida. Pond sizes ranged from 0.10 0.37 ha. Ponds 1 through 4 were in sandhills that had been invaded by hardwoods and sand pine (Pinus clausa) following decades of fire suppression. Ponds 1 through 3 were adjacent $(10-30 \mathrm{~m})$ to regularly burned sandhills on one side, separated by a sand road; Pond 4 was about $560 \mathrm{~m}$ north of the savanna-like sandhills. Since 1984, habitat restoration has been attempted unsuccessfully at 1-4-yr intervals by burning; nevertheless hardwood density remained high (but variable) around those ponds. Ponds 5 and 6 were in an adjacent savanna-like sandhills with widely spaced longleaf pine trees, few hardwoods, and continuous wiregrass groundcover. Ponds 7 and 8 were within a similar, savannalike sandhills approximately $9.5 \mathrm{~km}$ south of the others. The savanna-like sandhills have been successfully burned (2-3-yr intervals) since 1976 (for a detailed description of the two upland matrices, see Greenberg 2001). Dipnetting during most years and intensive box-sampling during 2000-2001 (A. Storfer, C. H. Greenberg, and G. W. Tanner, unpubl. data) indicated that all ponds were fish-free.

Drift Fence Sampling.--Drift fences 7.6-m long and spaced $7.6-\mathrm{m}$ apart encircled $50 \%$ of each pond. Pitfall traps (19-liter buckets) were positioned on the inside and outside of both ends of each fence (four per fence) to detect directional movement by amphibians to and from ponds. A sponge was placed in each pitfall trap and moistened at each trapcheck to reduce the likelihood of desiccation. A double- or single-ended funnel trap was positioned at the midpoint of each fence on both sides (two per fence), and a vertically positioned PVC pipe was placed between each fence to attract treefrogs.

Traps were checked three times weekly from February 1994 through January 2003. When capture rates were low all first-captured individuals were measured to the nearest $\mathrm{mm}$, weighed to the nearest $0.1 \mathrm{~g}$ using a hand-held Pesola spring scale, sexed (if possible) and marked by pond number and year of capture by toe clipping. During explosive breeding events, only a subsample (approximately 30 per pond) of adults were measured and weighed, but all were sexed and toe-clipped. Similarly, newly metamorphosed toads were counted, but only a subsample was measured when they emigrated en masse; most were too small (approximately $\leq 11 \mathrm{~mm}$ ) to practicably toe-clip. Recaptured toads were not measured. Animals were released on the opposite side of the fence from capture point.

Water depths were measured weekly at each pond beginning in March 1994. Temperature and rainfall were recorded daily at $0700 \mathrm{~h}$ beginning in April 1994. Beginning in January 1997, minimum and maximum daily air temperature also were recorded manually, and barometric pressure and relative humidity were recorded using Hobo data loggers (Onset Computer Corp., Pocasset, MA) at approximately 3 -h intervals. Hence, our complete weather dataset encompasses a 6-yr period (January 1997 to January 2003) excluding a few multiday gaps when automatic data loggers were temporarily off-line.

Statistical Analysis. - We correlated landscapelevel (data from all ponds combined) movement 
(captures per 2-3-day trapcheck interval) of firstcaptured adults with weather variables. We used an all possible correlations technique to select the best combination of variables for our model; only significant variables that contributed $\geq 0.05$ to the $R^{2}$-value were included. Variables were cumulative rainfall, mean minimum temperature, minimum temperature, mean maximum temperature, maximum temperature, mean daily temperature, mean daily barometric pressure, minimum barometric pressure, maximum barometric pressure, maximum change in barometric pressure, mean daily relative humidity, minimum humidity, maximum relative humidity, and maximum change in relative humidity per 2-3day trapcheck interval, as well as an interaction term between cumulative precipitation and maximum change in barometric pressure per 2-3-day trapcheck interval. Because spadefoot toads can breed during any season, they are capable of responding to weather variables at any time of year. Therefore, we used data from the entire 9-yr study period for adults.

Metamorphic movements are clearly restricted to the postmetamorphic period beginning about 2-3 weeks after an explosive breeding event and extending for about two months. Hence, for correlations of metamorphic movement with weather, we restricted our metamorph data to the period of "potential" movement, from the first capture of an emigrating metamorph and for two months thereafter. Our complete weather dataset (all variables were measured concurrently for only six of the nine years) corresponded only with two periods of movement by metamorphs (one each in 2000 and 2001), and the number of metamorphs recruited differed dramatically between those two periods. Hence, we used only the complete 9-yr rainfall data (cumulative rainfall per trapcheck interval) to determine whether rain was associated with metamorphic movements at a landscape level (ponds combined).

We also used the all possible correlations technique to explore the relationship between precipitation and hydrological conditions at ponds, and explosive breeding events at specific ponds. For this, we used only the subset of data that related to the nine dates when explosive breeding events (defined as $\geq 25$ first-captured adults during a given month at any given pond) occurred. Potential variables included pond depth at breeding date, the number of days since the pond was last dry $(\leq 2 \mathrm{~cm}$ depth), precipitation during the month prior to breeding date, precipitation during the week prior to breeding date, change in pond depth during the month prior to breeding date, change in pond depth during the week prior to breeding date, and interactions between the number of days since last dry and precipitation during the past month, days since last dry and change in pond depth change in previous month, days since last dry and rainfall during the past week, and days since last dry and change in pond depth during the past week. Variables that contributed $<0.05$ to the $R^{2}$-value were omitted from our model. We visually inspected data plots and used squareroot transformations on dependant data in all correlations to reduce heteroscedasticity.

We obtained an azimuth from the center of each pond to every pitfall trap using a compass. Under the assumption that captures by intermittent, equally spaced drift fences permitted detection of directional movement in some (if not $50 \%$ ) proportion to its occurrence, we used the nonparametric Rayleigh test (Zar, 1984) to determine (if $N \geq 30$ ) whether the annual movements of adults or metamorphs into or from ponds was nonrandom. Only first-captures were used for all analyses. Significance is reported at the $P<0.05$ level.

\section{RESULTS}

Upland Matrix Treatment Effects.--Number (per 100 trapnights) of total adults, total metamorphs, or emigrating metamorph captures did not differ between ponds within hardwood-invaded and savanna-like longleaf pine-wiregrass upland matrix. A year effect was detected for adults but not for total or emigrating metamorphs. Adult pond use was highest during years 1 and 7 , and least during years 4 and 9 (Table 1). A repeated-measures effect was significant for adults, indicating that the repeated use of specific ponds within treatments affected results.

Rainfall and Pond Hydrology.-During February 1994 to January 2003, pond depths ranged from 0-2 m (Fig. 1). Generally, pond depths peaked during September or October and reached their lowest levels during May. Locally, annual rainfall averaged $159 \mathrm{~cm}$ (range $130 \mathrm{~cm}$ in 2000 to $189 \mathrm{~cm}$ in 2002). On average, June to October were wettest, receiving on average $66 \%$ of total annual precipitation, whereas November to May were relatively dry months, receiving on average $35 \%$ of annual rainfall. Heavy rains associated with el Niño in 1998 resulted in record high water levels in ponds (Fig. 1) and flooded many traps during mid-February to May.

Depth and hydroperiod were similar among ponds, although there was one intermittently dry or very shallow pond in each upland matrix treatment (Ponds 3 and 7 ). Ponds dried $(<2 \mathrm{~cm}$ depth) and refilled 5-10 times each during the 9yr study period. All ponds were simultaneously dry five times: April to May 1994; May to July 2000; May 2001; July 2001; and May 2002. Drydown periods ranged from one day (Ponds 5 and 8) to 173 weeks (Pond 7), with the maximum 
TABLE 1. Mean ( \pm SE) annual (February 1994 to January 2003) number (per 100 trapnights) of adults, metamorphs, and emigrating metamorphic spadefoot toads at isolated ephemeral ponds within regularly burned, savanna-like $(N=4)$ versus long-unbumed, hardwood-invaded $(N=4)$ longleaf pine-wiregrass sandhills. Means for emigrating metamorphs are larger than for all metamorphs because only half of all traps (hence, trapnights) were positioned to capture exiting animals. P-values $<0.05$ indicate significant differences between treatments $(\mathrm{df}=1)$ or among years $(\mathrm{df}=8)$, interaction effects $(\mathrm{df}=8)$, or repeated measures effects $(\mathrm{df}=6)$, respectively (using repeated measures ANOVA). Different superscript letters among rows denotes which years differed significantly.

\begin{tabular}{|c|c|c|c|c|c|c|}
\hline \multirow[b]{2}{*}{ Year } & \multicolumn{2}{|c|}{ All adults } & \multicolumn{2}{|c|}{ All metamorphs } & \multicolumn{2}{|c|}{ Emigrating metamorphs } \\
\hline & Hardwood & Savanna & Hardwood & Savanna & Hardwood & Savanna \\
\hline 1 & $0.31 \pm 0.21$ & $0.73 \pm 0.47^{i}$ & $5.67 \div 5.64$ & $0.00 \pm 0.00$ & $10.70 \pm 10.68$ & $0.00 \pm 0.00$ \\
\hline 2 & $0.39 \pm 0.36$ & $0.09 \pm 0.07^{\mathrm{a}, \mathrm{b}, \mathrm{c}}$ & $3.14+3.07$ & $0.00 \pm 0.00$ & $4.44 \pm 4.51$ & $0.00 \pm 0.00$ \\
\hline 3 & $0.10+0.10$ & $0.02+0.01^{\mathrm{b}, \mathrm{c}}$ & $0.04 \pm 0.03$ & $0.00 \pm 0.00$ & $0.06 \pm 0.05$ & $0.00 \pm 0.00$ \\
\hline 4 & $0.01 \pm 0.01$ & $0.00+0.00^{\circ}$ & $0.00 \pm 0.00$ & $0.00 \pm 0.00$ & $0.00 \pm 0.00$ & $0.00 \pm 0.00$ \\
\hline 5 & $0.19+0.17$ & $0.10 \pm 0.05^{a, b, c}$ & $0.00 \pm 0.00$ & $0.00 \pm 0.00$ & $0.00 \pm 0.00$ & $0.00 \pm 0.00$ \\
\hline 6 & $0.10 \pm 0.05$ & $0.06 \pm 0.04^{a b c c}$ & $0.00 \pm 0.00$ & $0.00 \pm 0.00$ & $0.00 \pm 0.00$ & $0.00 \div 0.00$ \\
\hline 7 & $0.38 \pm 0.23$ & $0.60 \pm 0.36^{\mathrm{a}}$ & $0.04 \pm 0.02$ & $8.51 \pm 4.92$ & $0.06 \pm 0.04$ & $16.00 \pm 9.24$ \\
\hline 8 & $0.25 \pm 0.13$ & $0.44+0.20^{a, b}$ & $0.00 \pm 0.00$ & $0.42 \pm 0.37$ & $0.00 \pm 0.00$ & $0.25 \pm 0.22$ \\
\hline 9 & $0.00 \pm 0.00$ & $0.01 \pm 0.00^{\circ}$ & $0.00 \pm 0.00$ & $0.00 \pm 0.00$ & $0.00 \pm 0.00$ & $0.00 \pm 0.00$ \\
\hline$P_{t r t}$ & 0.7414 & & 0.9561 & & 0.9808 & \\
\hline$P_{\mathrm{yr}}$ & $<0.0001$ & & 0.1613 & & 0.1644 & \\
\hline$P_{\text {trtityr }}$ & 0.7959 & & 0.0658 & & 0.0703 & \\
\hline Prepeat & $<0.0001$ & & 0.4411 & & 0.4823 & \\
\hline
\end{tabular}

single period of continuous dryness ranging from 12 weeks (Ponds 1 and 2) to 173 weeks (Pond 7). Over the 9 -yr study period, ponds were dry $3.4 \%$ (Pond 5) to $81.5 \%$ (Pond 7) of the time.

Most (6 of 9) breeding periods occurred during September or October, but breeding also occurred during June, February, and March. Breeding was explosive, with up to 338 adults captured at a single pond within a 1-2-day period but rarely during nonbreeding periods. Only 1-5 ponds were used for breeding events per period, and breeding occurred during seven of the nine years reported. A total of 2986 individual adults were captured over the nine years.

An interaction between cumulative rainfall and maximum change in barometric pressure was selected as the top weather predictor of adult spadefoot toad movement at a landscape level (ponds combined; $F_{1,840}=350.21 ; P<0.0001$; $R^{2}=0.29$; $R M S E=1.20$ ). No other variables contributed $>0.05$ to the $R^{2}$-value. Rarely did precipitation $<8.6 \mathrm{~cm}$ within a $2-3$-day period elicit a breeding response (Fig. 2).

A total of 15,145 metamorphs were captured during the 9 -yr study period; $13,559(89.5 \%)$ were captured exiting ponds. Metamorphic movement was not correlated with cumulative rainfall per trapcheck interval $\left(F_{1,100}=0.14 ; P=0.7064\right.$; Fig. 2). Most (88.2-99.7\%) metamorphs exited ponds within a week of the first-captured emigrating metamorph, beginning 16-29 days after a breeding event at any given pond (Table 2).

Among variables tested, only precipitation $(P=0.0002)$ and change in pond depth during the month prior to breeding $(P=0.0023)$ were selected as top predictors of the number of breeding adults per pond per breeding event $\left(F_{3,69}=14.32 ; P<0.0001 ; R^{2}=0.29\right.$; RMSE $=$ 4.14). Figure 3 depicts the numeric response of adults to the number of days since a pond was last dry on the date of each breeding event. Most breeding events (17 of 22 ) occurred within 73 days of ponds refilling after a complete drydown; all large breeding events were in ponds that had refilled within the past 52 days. However, some smaller breeding events occurred in ponds up to 1944 days after the last dry-down.

Orientation.--Twenty-two of 27 tested adult immigration and emigration movements were significantly directional (11 of 14 immigrations and 11 of 13 emigrations; Table 3). Because toeclips were not specific, we could not track directional movements by individual spadefoot toads. However, mass movements by firstcaptured adults suggest that they returned toward their point of origin in some cases but not others. For example, on two occasions (1994 and 2000), the majority of first-captured adults entered or exited Pond 1 in approximately a straight-line direction, suggesting that they did not return to their upland area of origin (Table 3). Conversely, at Ponds 5 and 6 firstcaptured adults tended to exit ponds in the same general area as the mean angle of entry (e.g., the mean emigration angle was approximately the reverse of the mean immigration angle).

All tested metamorphic movements were significantly directional. In general, far fewer 

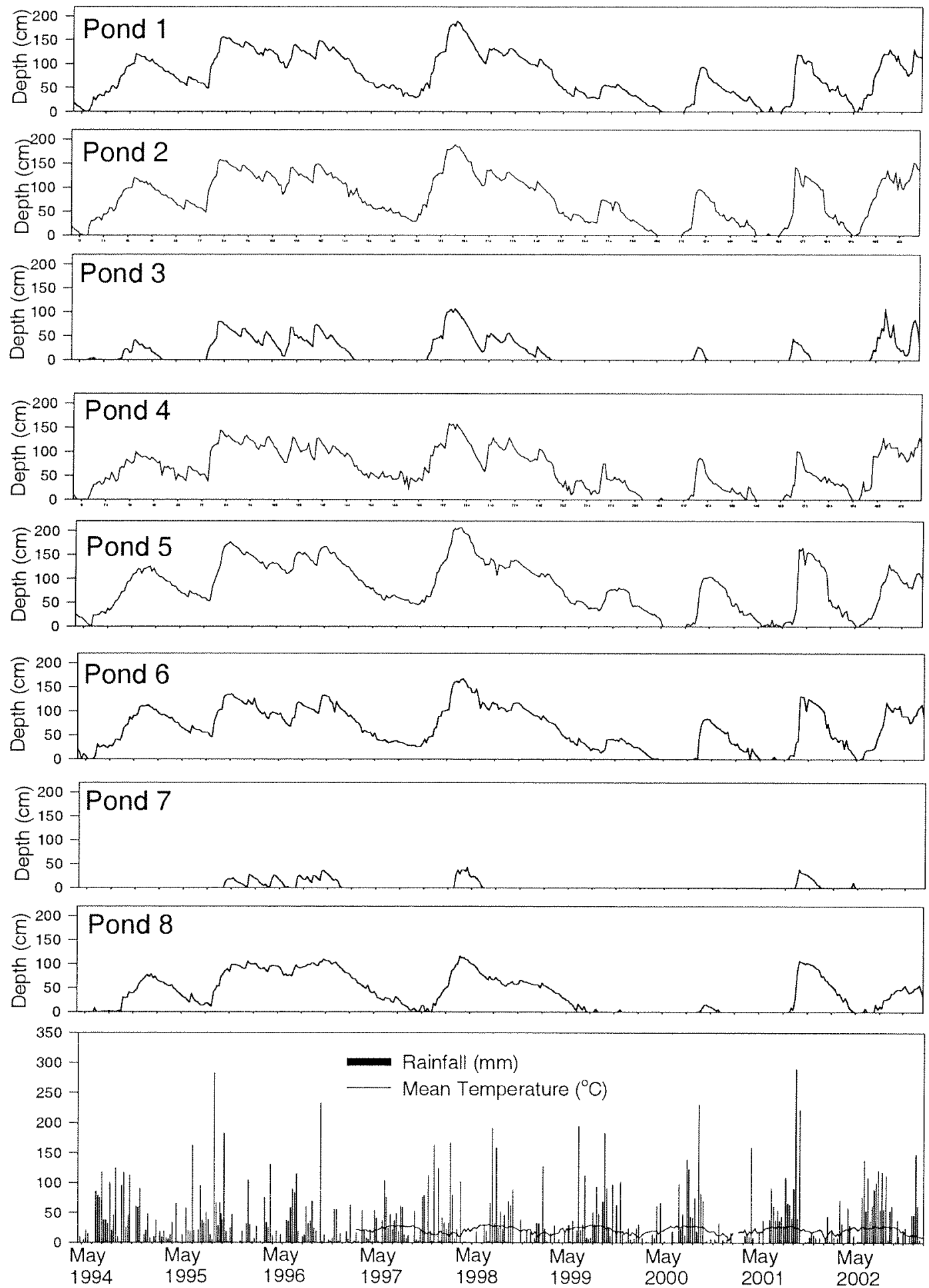

Fic. 1. Monthly precipitation, mean temperature, and depth of eight isolated, ephemeral ponds within longleaf pine-wiregrass sandhills, Ocala National Forest, Marion and Putnam counties, Florida. 

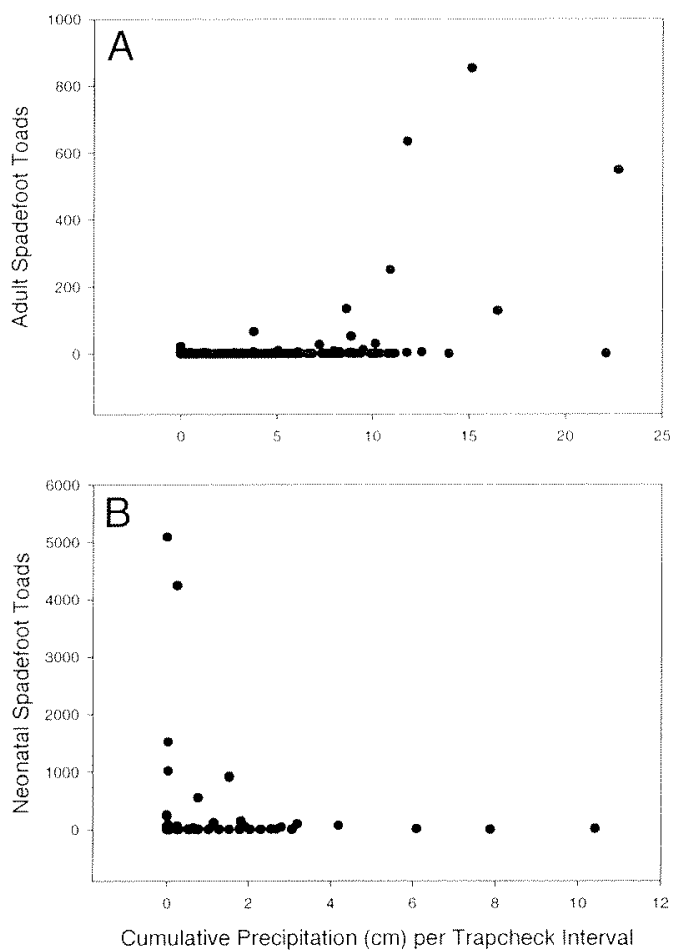

Fic. 2. Relationship between two- and three-day cumulative precipitation and two- and three-day firstcaptures of (A) adult and (B) metamorphic $(577 \mathrm{~mm}$ SVL) spadefoot toads (only from date of first emigration and for wo months thereafter) at eight (combined) isolated, ephemeral ponds within longleaf pine-wiregrass sandhills, Ocala National Forest, Marion and Putnam counties, Forida.

immigrating than emigrating metamorphs were captured at a pond during a given recruitment period. Most metamorphs entering ponds likely originated at that pond (successful, simultaneous recruitment at $>1$ pond occurred only once) and were generally captured close to exiting metamorphs (Table 3). Significant recruitment occurred at the same pond during $>1 \mathrm{yr}$ only twice; the direction of metamorph emigration was similar during 1995 and 1996 at Pond 3, and during 2000 and 2001 at Pond 5 (Table 3).

\section{DISCUSSION}

The sporadic nature of spadefoot toad breeding, usually in response to heavy rains during frontal weather, has been noted by several natural historians (Pearson, 1955; Wright, 2002). Gosner and Black (1955) reported that a minimum of $2 \mathrm{~cm}$ of rainfall within a few hours elicited breeding in New Jersey. They noted that breeding was prompted by either heavy rainfall during a short time period, or by prolonged rainfall extending over several days. We found that, at a landscape level, heavy rains falling within a 1-3-day period, maximum change in barometric pressure, and an interaction between those two variables were significant predictors of spadefoot toad breeding events. However, many heavy rainfall events did not elicit breeding, even if they occurred long after the most recent breeding period. Gosner and Black (1955) also noted that heavy rainfall did not always elicit breeding by spadefoot toads in New Jersey and that local populations, or even individuals did not always respond similarly to rainfall.

Although we found no published records of S. holbrookii breeding during winter, they bred in small numbers at two of our study ponds (Ponds 3 and 6) on 19 February 1998. Soil temperature and moisture may affect emergence for breeding (Gosner and Black, 1955). In our study, other breeding events occurred during June, September, October, and March.

Rainfall and change in pond depth partially explained pond selection by adults for breeding. Adults usually selected ponds for breeding that had recently dried completely and refilled, and all large breeding events occurred in ponds that had held water for $\leq 52$ days. However, this was clearly not the sole governing factor in pond selection for breeding, as only a subset of seemingly suitable ponds were used for breeding during any given period.

Length of time between breeding and date of first metamorph emigration from a pond ranged from 16-29 days. Other reports of larval developmental rates range from $14-35$ days in the wild (Bragg, 1961; Wright, 2002), and from 9 to 86 days in the laboratory (Gosner and Black, 1955; Semlitsch and Caldwell, 1982). Rapid larval development could prevent desiccation in rapidly drying ponds (Newman, 1989), clearly an advantage for temporary pond breeders. In laboratory experiments, growth and rate of larval development of spadefoot toads were negatively influenced by density (Semlitsch and Caldwell, 1982) and positively affected by water temperature (within the $10-29^{\circ} \mathrm{C}$ range; Gosner and Black, 1955). Newman (1989) reported that Couch's Spadefoot Toad (S. couchii) tadpole development was accelerated under conditions of high food availability and short pond duration, but body size was smaller at metamorphosis than for individuals taking longer to complete development. In our study, cooler water temperatures may have delayed larval development during late fall compared to summer or early fall. However, differences in developmental rates were unrelated to pond hydroperiod, since none of our ponds dried for several months postbreeding.

Transformation date, rather than any weather variable, appeared to strongly affect emigration by metamorphs. Nearly all emigration was 
TABLE 2. Breeding date, total number, date of first known emigration, number of days from breeding to metamorphosis, proportion emigrating after first day and first week, date of last known emigration, and (maximum) number of days between breeding and last known emigration of spadefoot toad metamorphs following successful recruitment $(N \geq 100$ metamorphs exiting a pond) from eight isolated, ephemeral ponds during nine years (February 1994 to January 2003), Ocala National Forest, Marion and Putnam counties, Florida.

\begin{tabular}{|c|c|c|c|c|c|c|c|c|}
\hline $\begin{array}{l}\text { Breeding } \\
\text { date }\end{array}$ & $\begin{array}{l}\text { Pond } \\
\text { ID }\end{array}$ & $\begin{array}{l}\text { Total no. } \\
\text { metamorphs }\end{array}$ & $\begin{array}{l}\text { Date lst } \\
\text { emigration }\end{array}$ & $\begin{array}{l}\text { No. days } \\
\text { to metamorph. }\end{array}$ & $\begin{array}{l}\text { Emigrations } \\
1 \text { st day }(\%)\end{array}$ & $\begin{array}{l}\text { Emigrations } \\
\text { lst week }(\%)\end{array}$ & $\begin{array}{l}\text { Date last } \\
\text { emigration }\end{array}$ & $\begin{array}{c}\text { Max days to } \\
\text { last emigration }\end{array}$ \\
\hline $6-23-94$ & 1 & 4648 & $7-11-94$ & 18 & 88.1 & 99.7 & $7-27-94$ & 34 \\
\hline $10-13-95$ & 3 & 1392 & $11-6-95$ & 29 & 15.4 & 88.2 & $5-13-96$ & 212 \\
\hline 9.11 .00 & 5 & 3771 & $9-29-00$ & 18 & 11.3 & 99.7 & $12-11-00$ & 91 \\
\hline $9-11-00$ & 6 & 3579 & $9-27-00$ & 16 & 2.0 & 99.1 & $11-1000$ & 60 \\
\hline $9-16-01$ & 5 & 111 & $11-14-01$ & 28 & 24.3 & 82.9 & $12-13-01$ & 88 \\
\hline
\end{tabular}

complete within a week after the date of first metamorph emigration from a pond. In contrast, Abbott (1904 in Neill, 1957) suggested that spadefoot metamorphs remain near their natal ponds and emigrate after a heavy rain. In our study, a few metamorphs remained at their natal ponds for up to 212 days, but the vast majority emigrated shortly after metamorphosis regardless of rainfall.

Several accounts note mass movements of metamorphic spadefoot toads exiting ponds in specific directions (Neill, 1957; Wright, 2002). We found significantly nonrandom movement by emigrating metamorphs for each of the six $(N \geq$ 30 individuals) movements tested. Because recruitment was rarely successful at the same pond in multiple years, we could not determine whether the direction of movement from a pond was similar during successive years. Directional movement by emigrating metamorphs likely can be attributed to the aggregational behavior of spadefoot toad tadpoles until metamorphosis (Neill, 1957; Bragg, 1968). We observed spadefoot toad tadpole aggregations at Ponds 1,5, and 6 during box-sampling for tadpoles during 2000 (A. Storfer, C. H. Greenberg, and G. W. Tanner, unpubl. data).

Adult immigrations and emigrations at our study ponds also were highly directional in most, but not all, cases. Because we did not mark toads individually (but rather by pond and cohort number), we were unable to determine whether individuals exited ponds in the general direction of their origin. However, the average direction of movement by first-captured adults differed among years at the same ponds, suggesting that they were coming from or going to different areas. In addition, several movements indicated that adults entered and exited ponds in a straight-line direction (e.g., Pond 1, 1994, and 2000), whereas others (e.g., Ponds 5 and 6) indicated that adults exited ponds toward their apparent area of origin. Gosner and Black (1955) suggest that different cohorts of a spadefoot toad population may breed at different times, perhaps explaining some of our observed differences in directional movement among years at the same pond.

Forest succession, and associated changes in habitat such as increased canopy cover, can negatively impact amphibian populations (Skelly et al., 1999). Pearson (1955) found that spadefoot toads are most common in forests without considerable leaf detritus and low shrub cover. In contrast, our data indicate that hardwood and sand pine invasion into xeric sandhills caused by fire suppression does not affect adult pond use or recruitment. However, this conclusion must be treated cautiously because the level of hardwood invasion was patchy, and the short distance $(<30 \mathrm{~m})$ between three of the ponds within the hardwood-invaded treatment and the savannalike habitat. Although ponds within both upland matrix treatments were rarely used for breeding, Pond 4 , which was $>560 \mathrm{~m}$ from savanna-like sandhills, was never used.

Our data on metamorph and adult movements to or from ponds suggest that spadefoot toads are not restricted to regularly burned, savanna-like

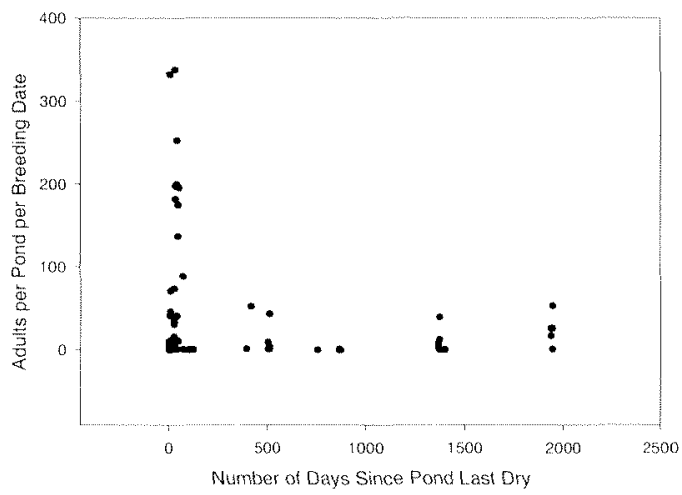

Fic. 3. Relationship between length of time since ponds were last dry (days) and the number of adults breeding at each of eight ponds during each of nine explosive breeding dates (when $\geq 25$ adults used any single pond within a months period), Ocala National Forest, Marion and Putnam Counties, Florida. 
TABLE 3. Orientation of adult $(A)$ and metamorphic $(M)$ spadefoot toads entering (En) or exiting (Ex) eight isolated, ephemeral ponds in the Ocala National Forest, Putnam and Marion Counties, Florida. Only ponds and years having $N \geq 30$ individuals per age/direction class are included. Mean azimuths are absolute, such that individuals entering and exiting at the same angle are traveling in a straight-line direction. Significantly directional movement (determined by Rayleigh's test) is denoted by asterisks ${ }^{* * *}=P<0.001 ; * * *=P<0.005$; $*=P<0.05$ ).

\begin{tabular}{|c|c|c|c|c|c|c|c|}
\hline Year & $\begin{array}{l}\text { Pond } \\
\text { no. }\end{array}$ & Age & Direction & $N$ & $\begin{array}{c}\text { Mean } \\
\text { azimuth (o) }\end{array}$ & $R$ & $Z_{\text {calc }}$ \\
\hline 1994 & 1 & $\mathrm{~A}$ & En & 118 & 93 & 41.4 & $14.5089^{* * * 4}$ \\
\hline 1994 & 1 & $\mathrm{~A}$ & Ex & 81 & 107 & 26.2 & $8.4502^{* * * 4}$ \\
\hline 1994 & 1 & M & En & 266 & 19 & 223.9 & $188.484^{* * * *}$ \\
\hline 1994 & 1 & $\mathrm{M}$ & $\mathrm{Ex}$ & 4648 & 160 & 3520.2 & $2666.0396^{* * x *}$ \\
\hline 1999 & 1 & $\mathrm{~A}$ & Ex & 37 & 15 & 24.3 & $16.0168^{* * *}$ \\
\hline 2000 & 1 & $\mathrm{~A}$ & En & 133 & 24 & 70.3 & $37.1649^{* * * *}$ \\
\hline 2000 & 1 & $\mathrm{~A}$ & Ex & 122 & 33 & 63.6 & $33.1654^{* * * 6}$ \\
\hline 2001 & 1 & $\mathrm{~A}$ & En & 41 & 41 & 13.6 & $4.5070^{*}$ \\
\hline 2001 & 1 & A & Ex & 97 & 166 & 50.0 & $25.7305^{* * * x}$ \\
\hline 1995 & 3 & A & En & 153 & 58 & 20.5 & 2.7382 (NS) \\
\hline 1995 & 3 & $\mathrm{~A}$ & Ex & 70 & 69 & 24.7 & $8.7103^{* x}$ \\
\hline 1995 & 3 & $\mathrm{M}$ & En & 502 & 185 & 304.8 & $185.111^{* * *}$ \\
\hline 1995 & 3 & $\mathrm{M}$ & $\mathrm{Ex}$ & 1365 & 24 & 995.6 & $726.1039^{* * 4 * 4}$ \\
\hline 1996 & 3 & A & En & 30 & 150 & 18.5 & $11.3997^{* * * *}$ \\
\hline 1996 & 3 & $\mathrm{M}$ & Ex & 39 & 25 & 14.9 & $5.7236^{* *}$ \\
\hline 1998 & 3 & A & En & 52 & 177 & 6.8 & 0.8991 (NS) \\
\hline 1998 & 3 & $\mathrm{~A}$ & Ex & 40 & 1 & 13.6 & $4.6224^{*}$ \\
\hline 2001 & 3 & A & Ex & 33 & 135 & 6.3 & 1.1999 (NS) \\
\hline 1994 & 5 & $\mathrm{~A}$ & En & 38 & 17 & 28.7 & $21.6640^{* * *}$ \\
\hline 1994 & 5 & A & Ex & 37 & 167 & 26.5 & $19.0248^{* * *}$ \\
\hline 2000 & 5 & $\mathrm{~A}$ & En & 114 & 7 & 46.9 & $19.3043^{* * *}$ \\
\hline 2000 & 5 & $\mathrm{~A}$ & $\mathrm{Ex}$ & 89 & 138 & 43.8 & $21.5277^{* * *}$ \\
\hline 2000 & 5 & $M$ & En & 463 & 38 & 405.9 & $355.8275^{* * *}$ \\
\hline 2000 & 5 & $\mathrm{M}$ & $\mathrm{Ex}$ & 3771 & 146 & 3301.9 & $2891.1113^{* * * *}$ \\
\hline 2001 & 5 & $\mathrm{~A}$ & En & 119 & 29 & 90.2 & $68.4310^{* * *}$ \\
\hline 2001 & 5 & A & $\mathrm{Ex}$ & 57 & 160 & 51.0 & $45.5867^{* * *}$ \\
\hline 2001 & 5 & $\mathrm{M}$ & En & 252 & 53 & 234.0 & $217.3296^{* * *}$ \\
\hline 2001 & 5 & $\mathrm{M}$ & Ex & 111 & 116 & 91.9 & $76.0100^{* * * *}$ \\
\hline 1994 & 6 & $\mathrm{~A}$ & En & 241 & 10 & 108.8 & $49.1365^{* * *}$ \\
\hline 1994 & 6 & A & Ex & 99 & 169 & 24.6 & $6.0913^{* *}$ \\
\hline 1995 & 6 & $\mathrm{~A}$ & En & 37 & 4 & 27.1 & $19.8984^{* * * *}$ \\
\hline 2000 & 6 & $\mathrm{~A}$ & En & 164 & 6 & 30.8 & $5.7844^{* *}$ \\
\hline 2000 & 6 & A & Ex & 168 & 171 & 15.8 & 1.4856 (NS) \\
\hline 2000 & 6 & $\mathrm{M}$ & $\mathrm{Ex}$ & 3579 & 19 & 3509.1 & $3440.5866^{* * *}$ \\
\hline 2001 & 6 & $\mathrm{~A}$ & En & 97 & 43 & 20.2 & $4.1911^{*}$ \\
\hline 2001 & 6 & $\mathrm{~A}$ & Ex & 86 & 133 & 33.1 & $12.7218^{* * * *}$ \\
\hline 1994 & 8 & $\mathrm{~A}$ & $\mathrm{En}$ & 50 & 172 & 10.8 & 2.3223 (NS) \\
\hline
\end{tabular}

sandhills. The direction of adult immigration at Pond 3 during 1995 and 1996 indicated that they were moving from hardwood-invaded sandhills to the north, rather than the adjacent savannalike sandhills to the south. Adults emigrated toward the hardwood-and sand-pine-invaded forest north of Pond 1 during 1999 and 2000. Emigration (and immigration) by recent metamorphs was in the direction of hardwoodinvaded sandhills, rather than the adjacent savanna-like sandhills surrounding Pond 3 during 1995 and 1996. Neill (1957) also noted a mass movement of spadefoot toadlets heading toward a "dense mesic wood."

Our results suggest that spadefoot toads are highly adapted to breeding conditions and upland habitat heterogeneity created by weather patterns and fire frequency in Florida sandhills. In the uplands, spadefoot toads appear tolerant of hardwood invasion, at least where it is patchy and relatively close to savanna-like sandhills. This may be an adaptation to historical heterogeneity in hardwood densities in xeric sandhills because of spatial and temporal patchiness of fire 
(Myers, 1990; Greenberg and Simons, 1999). Rainfall patterns strongly influence both spatial and temporal patterns of spadefoot toad breeding. Wet-dry cycles influence where breeding occurs at the landscape level by creating suitable hydrological conditions at ponds (drying, then refilling), and heavy rains influence the temporal patterns of spadefoot toad breeding biology by potentially eliciting an explosive breeding response.

Acknowledgments.-Funding was provided by the USDA Forest Service, including the Ocala National Forest, the Longleaf Pine Ecosystem Restoration Program, and the Southern Research Station's Bent Creek Experimental Forest; the Department of Energy-Savannah River Operations office through the Forest Service Savannah River Site and the Forest Service Southern Research Station under Interagency Agreement DE-AI09-76SR00056; and the Florida Fish and Wildlife Conservation Commission, Bureau of Wildlife Diversity Conservation, contracts NG99-014 and C1195. We thank J. Beach for field and logistical assistance and for her dedication to this study. C. McMahon, D. Loftis, and J. Blake provided critical support to the study. R. Ashton, M. Welker, J. Smith, J. Staiger, J. Barichivich, R. Owen, D. Johnson, S. Johnson, J. Wiebe, K. Garren, and others have provided excellent field assistance and/or onsite project management. D. Johnson created the study site map. We also thank Ocala National Forest staff officers, including L. Lowery, R. Lowery, C. Sekerak, J. Clutts, and M. Clere, and the Ocala fire crew. J. Petranka, S. Johnson, K. Kinkead, D. C. Forester, and an anonymous reviewer gave valuable suggestions for improving earlier versions of this manuscript.

\section{Literature Cited}

AlfORD, R. A. 1989. Variation in predator phenology affects predator performance in prey community composition. Ecology 70:206-219.

BraGG, A. N. 1961. The behavior and comparative developmental rates in nature of tadpoles of a spadefoot, a toad, and a frog. Herpetologica 17:80-84.

. 1968. The formation of feeding schools in tadpoles of spadefoots. Wasmann Journal of Biology 26:11-16

DELis, P. R., H. R. Musminsky, and E. D. McCoy. 1996. Decline of some west-central Florida anuran populations in response to habitat degradation. Biodiversity and Conservation 5:1579-1595.

GosNer, K. L., AND I. H. BlACK. 1955. The effects of temperature and moisture on the reproductive cycle of Scaphiopus h. holbrooki. American Midland Naturalist 54:192-203.
GreenberG, C. H., 2001. Spatio-temporal dynamics of pond use and recruitment in Florida Gopher Frogs (Rana capito aesopus). Joumal of Herpetology 35 : $74-85$.

Greenberg, C. H., and R. W. Simons. 1999. Age, composition, and stand structure of old-growth oak sites in the Florida high pine landscape: implications for ecosystem management and restoration. Natural Areas Journal 19:30-40.

Jansen, K. P. A. P. Summers, And P. R. Delis. 2001. Spadefoot toads (Scaphiopus holbrookii holbrookit) in an urban landscape: effects of non-natural substrates on burrowing in adults and juveniles. Journal of Herpetology 35:141-145.

Moler, P. E., AND R. Franz. 1987. Wildlife values of small, isolated wetlands in the southeastern coastal plain. In R. R. Odum, K. A. Riddleberger, and J. C. Ozier (eds.), Proceedings of the 3rd S. E. Nongame and Endangered Wildlife Symposium, pp. 234-241. Georgia Department of Natural Resources, Atlanta.

MYers, R. L. 1990. Scrub and high pine. In R. L. Myers and J. J. Ewel (eds.), Ecosystems of Florida, pp. 150193. Univ. of Central Florida Press, Orlando.

NEILL, W. T. 1957. Notes on metamorphic and breeding aggregations of the eastern spadefoot, Scaphiopus holbrooki (Harlan). Herpetologica 13:185-187.

NewMAN, R. A. 1989. Developmental plasticity of Scaphiopus couchii tadpoles in an unpredictable enviromment. Ecology 70:1775-1787.

Pearson, P. G. 1955. Population ecology of the spadefoot toad, Scaphiopus h. holbrooki (Harlan). Ecolog ical Monographs 25:233-267.

Petranka, J. W., and C. A. KenNedy. 1999. Pond tadpoles with generalized morphology: is it time to reconsider their functional roles in aquatic communities? Oecologia 120:621-631.

Semlitsch, R. D., and J. P. Cal.dwel.l. 1982. Effects of density on growth, metamorphosis, and survivorship in tadpoles of Scaphiopus holbrooki. Ecology 83:905-911

Skelly, D. K., E. E. Werner, and S. A. Cortwright, 1999. Long-term distributional dynamics of a Michigan amphibian assemblage. Ecology 80:2326-2337.

WELLS, K. D. 1977. The social behavior of anuran amphibians. Animal Behavior 25:666-693.

Wilbur, H. M. 1987. Regulation of structure in complex systems: experimental temporary pond communities. Ecology 68:1437-1452.

Wilbur, H. M., P. J. Mokin, and R. N. Harres 1983. Salamander predation and the structure of experimental communities: anuran responses. Ecology 64:1423-1429.

WRIGHT, A. H. 2002. Life-Histories of the Frogs of the Okefinokee Swamp, Georgia. North American Salientia (Anura) No. 2. Cornell Univ. Press, Ithaca, NY.

ZAR, J. H. 1984. Biostatistical Analysis. Prentice Hall, Englewood Cliffs, NJ.

Accepted: 31 August 2004. 